\title{
IMPACT OF AGRICULTURAL DIVERSIFICATION ON AGRICULTURAL ENTERPRISES AND RURAL DEVELOPMENT
}

\author{
Dragoljub Amidžićc ; Pavlo Ružić ${ }^{2}$
}

\begin{abstract}
The paper explores the diversification of agricultural enterprises, which seeks to extend basic farming activities to products of a higher degree of sophistication, such as the provision of catering and tourism services and the provision of entertainment, sports, educational and other facilities. The fundamental purpose of diversification is to ensure the growth and stability offarmers' businesses and to contribute to the rural development. The main objective of the paper is to identify factors of diversification and their correlation with socio-economic indicators. In addition to determining the extent to which they are present in improving the performance of agricultural enterprises and affect rural development. The results of the research will confirm the assumption that the inclusion of diversification in business practices of agricultural enterprises is a means of strengthening their performance while encouraging rural develompent.
\end{abstract}

Key Words: diversification, farm, rural development, correlation, socioeconomic indicators

JEL classification: $O 13, O 18, Q 12, R 51$

\section{Introduction}

Farms in Croatia as well as in other EU Member States play an important role in the development of agriculture and the overall progress of rural areas. In order to understand this role more fully, the more important dimensions of modern agriculture are explained. In Croatia, the traditional form of agriculture has existed for a long time, but in the last twenty years, under the influence of various factors, a modern agricultural economy has

\footnotetext{
${ }^{1}$ Dragoljub Amidžić, PhD, "Baltazar Adam Krčelić", Zaprešić, Croatia, 098221 131, email: dragoljub.amidzic@zg.htnet.hr

${ }^{2}$ Pavlo Ružić, PhD, Scientific adviser, Institute for Agriculture and Tourism Poreč, Croatia, 091555 8011, e-mail: pavlo@iptpo.hr
} 
gradually emerged, capable of competition and somewhat compatible with the European environment.

One of the prerequisites of modern agriculture is the larger technically well-equipped economy. It was on this trail that the efforts of state policy in the process of transition and privatization in agriculture led to a new structure of Croatian agriculture. There has been greater polarization in the ownership structure of agricultural holdings, in which a narrower stratum of larger and market-oriented holdings has been singled out, while at the same time a large number of dwarf and small estates exist, which retain many traditional characteristics. However, many problems remain and the overall situation in agriculture is still stagnant. In Croatia as well as in other EU member states there is a process of reducing the role of agriculture in the overall economy. This trend is evident in the decline in the share of agriculture in the most important macroeconomic indicators. Between 1995 and 2017, the share of agriculture in Croatia's gross value added decreased from $9.4 \%$ to $3.7 \%$ (Croatian Bureau of Statistics, 2018a). The decrease is also noticeable in the number of employees, so in the period from the first quarter of 2010 to the last quarter of 2018 the share of employees in agricultural activities decreased from $14.7 \%$ to $6.0 \%$ (Croatian Bureau of Statistics, 2018b). These processes are not only characteristic of the Croatian but also of the European agricultural sector and are part of various developmental economic and social processes which increase the share of services at the expense of agricultural activities in the structure of the total economy, while the share of industrial activities is generally stable. At EU level, the share of agriculture in gross domestic product decreased from 1995 to 2015 from $2.6 \%$ to $1.5 \%$. A quarter of agricultural holdings in the European Union disappeared between 2003 and 2013, while the total area of agricultural land used remained largely the same.

While larger farms are getting bigger by taking advantage of the economies of scale, small farms are a problem for society and countries, which under the new market conditions on small farmland do not generate sufficient income for their financial sustainability.

These factors cause deagrarization, that is, abandonment of agriculture as a source of income and occupation. Deagrarization creates multiple consequences in agriculture and rural areas. Deagrarization destroys the demographic structure and creates social problems among some categories of rural population (Puljiz, 2003). In order to mitigate the effects of deagriculturalisation, stabilize the income of small farmers and find new 
sources of income for those who have left agriculture, the rural population focuses on diversifying their activities inside and outside the agricultural sector (Falkowski et al., 2014; Franić \& Mikuš, 2013).

Diversification is a term that entered into professional practice and terminology in the 1980s. According to the Business Dictionary (Jurković et al., 1995), diversification is the completion or expansion of the product or sales range by including new products and services that are different from previous ones. These new products and services are offered in other market segments, produced with a different manufacturing process, and may have different usable value. This definition, adapted to the operation of agricultural holdings, and conditioned on the need for sustainable smallscale farmers (Ružić \& Amidžić, 2018), would refer to the production and services of agricultural holdings of higher added value and or higher degree of completion.

The pursuit of agricultural activity, like any other economic activity, requires a certain form of management, and therefore different types and forms of agricultural holdings have been developed. In this paper, we address the structure, development trends and contemporary problems of agricultural holdings in Croatia, as well as some broader aspects of the situation in agriculture and rural areas that are important for understanding the central theme of this paper. In Europe and in other developed countries, family farming is now prevalent as a form of agricultural production organization. More recently, this has also been extended to the European East, where until recently the state-owned agricultural property sector based on collective agriculture has existed.

We see that not only is what agriculture gives important, but many issues of the wider social, economic and political spectrum are linked to property and agriculture. As is the case with the wider complex of agriculture, a particular agricultural economy can be regarded not only as a better or worse, more propulsive or static model of economy, but also as an important factor in the development of the rural area in which it is located.

\section{Research methodology}

The research in this paper is based on primary and secondary sources, and approaches and methods based on the views of local and foreign authors. The paper aims to assess the effects of diversification of agricultural holdings with particular reference to its contribution to rural development. 
The effects of farm diversification have so far been the most widely investigated with a view to determining the contribution to their operations and enhancing the social product (Hadelan et al., 2019). In this paper, a correlation analysis (Hadelan et al., 2019) was used to determine the impact of farm diversification on rural development, which explored the linkage between agricultural holdings and the most important socioeconomic indicators. Subsequently, the impact of diversification on rural development was determined by linking it with data on the growth of gross value added per unit of work in agriculture, the size and type of farms, etc.

For the purposes of this research, data from the Central Bureau of Statistics for the Republic of Croatia were used. The basis for the correlation analysis is the secondary data of the Statistical Office of the European Union (Eurostat), which includes an overview of the representation of supplementary activities on EU agricultural holdings and socio-economic indicators of Member States' agricultural holdings. To determine the association between the observed variables, the Pearson linear correlation coefficient was calculated. The linearity of the connectivity was previously verified by making a scatterplot. The significance of the correlation coefficient was estimated at a significance level of $5 \%$, ie $p=0.05$.

Due to lack of recent research, data for the variable "Number of subsidiary industries" taken from Eurostat refer to 2013. For methodological correctness, the data of the variables for which correlation is determined also refer to the values from 2013, although for them and more recent records used in the descriptive section of the paper. A significant part of the paper is also of a review character, since it provides insight into earlier research on the subject (Hadelan et al., 2019).

\section{Research goals and hypotheses}

The basic objective of the research in the paper are to detect the effect of diversification of the agricultural economy on agricultural business and rural development. The specific objectives are first of all to identify the link between the share of diversified agricultural holdings in EU Member States and the most important socio-economic indicators of the agri-food sector, which are: how does diversification of farms affect the achievement of gross value added per unit of labor? what impact do supplementary activities have on the size and type of farms? and how do supplementary activities relate to the age and educational structure of farm employees? 
According to the stated goals, a hypothesis has been raised that argues that diversification is an important factor in the competitiveness and success of agricultural businesses and rural development.

The hypothesis will be tested on the example of Croatia and EU member states, based on the usual approach and methods known among domestic and foreign scientists and conducted research (Hadelan et al., 2019).

\section{Research results}

Diversification of farms by including supplementary activities contributes to an increase in gross value added per unit of labor, which indicates an increase in farmers' business activity. Increasing gross value added in the agricultural sector is a function of the complete development of the rural area in which agriculture is a major economic activity. Therefore, in the following, these issues will be analyzed integrally with the other socioeconomic consequences of diversification of the farm.

\section{Diversification of agricultural holdings and their impact on their business and rural development}

Eurostat keeps a record of supplementary activities on agricultural holdings, expressed as "other income-generating activities". According to this source for 2013, out of a total of 10,881,560 farms in the EU28, 734,640 were engaged in some additional income activity, which is $6.8 \%$ of all farms.

Figure 1: Share of farms with subsidiary activities in the EU28, data for 2013

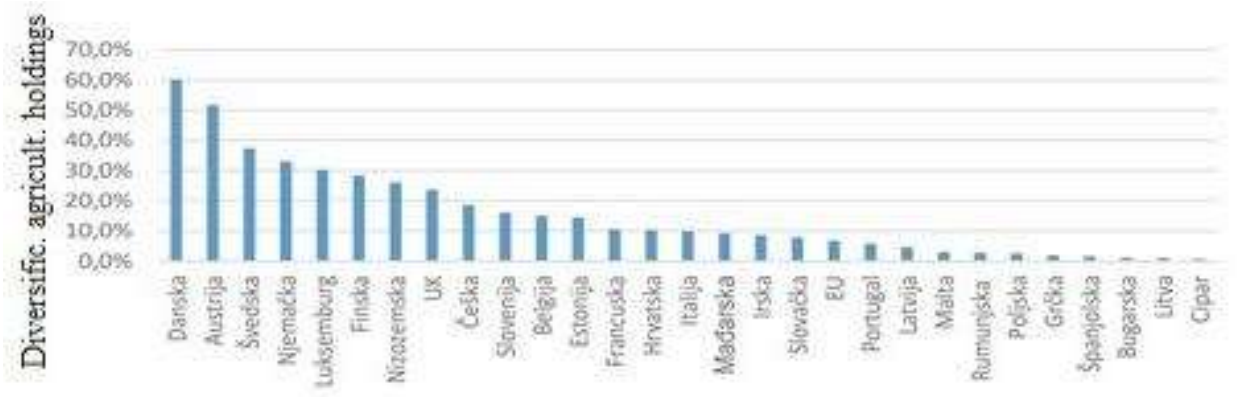

Source: Hadelan et al., 2019 
Here it is possible to notice significant differences in the shares of these activities in individual Member States. While they are present in more than $50 \%$ of all farms in Denmark and Austria, their share in Greece, Spain and Bulgaria is less than $2 \%$. The same source states that 16,240 Croatian holdings are engaged in additional activity, which is $10.3 \%$ of all agricultural holdings and counts Croatia among countries with aboveaverage diversified agricultural holdings in the EU28.

According to the same source in the EU28, the most common subsidiary activity of agricultural holdings is the processing of agricultural products, which accounts for $22.8 \%$ of all such activities. Agricultural products are processed from mostly their own production with the possibility of purchasing a smaller part of raw materials from other agricultural holdings. In addition to the processing of agricultural products, additional activities include the production of non-food products and general-purpose items at the farm (predominantly of wood, straw and similar natural materials in a manner characteristic of traditional skills), the provision of catering, tourism and other services (Ružić et al., 2006), the provision of educational and demonstration facilities and activities at the OPG. In Croatia, supplementary activities of agricultural holdings are regulated by the Ordinance on supplementary activities on family farms (Official Gazette 76/14), and each individual supplementary activity has its own legal regulation.

Diversification of farmers' activities is a function of integrated rural development, but also of integrating rural space into the overall national economy (Sudarić, 2009). Recently the potentials of diversification in achieving the sustainability of agricultural holdings have been recognized (Oplanić et al., 1997), positive demographic processes in rural areas and, indirectly, rural development (Župančić, 2005), shaping the measures of the Rural Development Program aimed at encouraging farmers to entrepreneurship in rural areas.

\section{Impact of farm diversification on the achievement of gross value added per unit of labor}

Gross value added (hereinafter referred to as GVA) is one of the most commonly used indicators of development in general and therefore agriculture of a country. It is determined by the difference in the market value of all agricultural products and intermediate production. The share of agricultural gross value added in the total gross value added of an economy 
indicates the importance of agriculture in a country's economy (Ružić \& Demonja, 2017). Increasing the gross value added of agriculture is a multiplier effect and, thanks to its connection with other economic activities, accelerates economic growth in the overall national economy (Mrówczyńska-Kamińska \& Baer-Nawrocka, 2016) but also in the rural area where it is realized.

GVA at current prices indicates the largest farmers in the European Union, according to Eurostat (2019b) for 2018, respectively - Italy, France, Spain and Germany. Of the 28 EU countries, Croatia is ranked 20th with a GVA of around one billion euros. Over the 10-year period (2008-2017) at EU28 level, GVA grew by $19.0 \%$. Of the 28 Union countries observed, only three Member States (Croatia, Finland, Romania) recorded a decline in GVA, of which it is most pronounced in Croatia (35.9\%). On the other hand, GVA in Ireland has more than doubled (111.4\% growth). Higher growth rates were also recorded in agriculture in Denmark (77.3\%) and Lithuania $(67.7 \%)$.

The relative value of GVA is obtained by dividing nominal value by units of annual labor (AWU) and such serves as an indicator of agricultural productivity. According to data for 2017 (Eurostat, 2018), the highest productivity in the EU was achieved by farmers in the Netherlands (EUR 74,732.32 / AWU), followed by farmers in France and Denmark. The lowest agricultural productivity was achieved in Latvia, with Croatia with a GVA / AWU ratio of EUR 5,827.93 per unit of work ranked 25th out of 28 EU Member States.

Applying the scatterplot and calculating the correlation coefficient graphically and mathematically, the correlation between agricultural productivity and the share of agricultural holdings with additional activities was determined. The assumption of the existence of a connection is reflected in the fact that the additional activities are those characterized by a higher degree of completeness and consequently higher added value. Countries with a higher share of diversified economies are expected to be the ones with higher productivity.

Applying the scatter plot shows a positive link between supplementary activities on agricultural holdings and agricultural productivity determined by the ratio of gross value added to annual labor units. The Pearson coefficient calculation confirmed the existence of a statistically significant 
correlation ( $\mathrm{p}=0.0082)$, which according to the value of the coefficient can be considered as medium strong and positive $(r=0.4902)$.

Figure 2: Field share ratio. mr. with supplementary activities and GVA per unit of work in the EU28, 2013

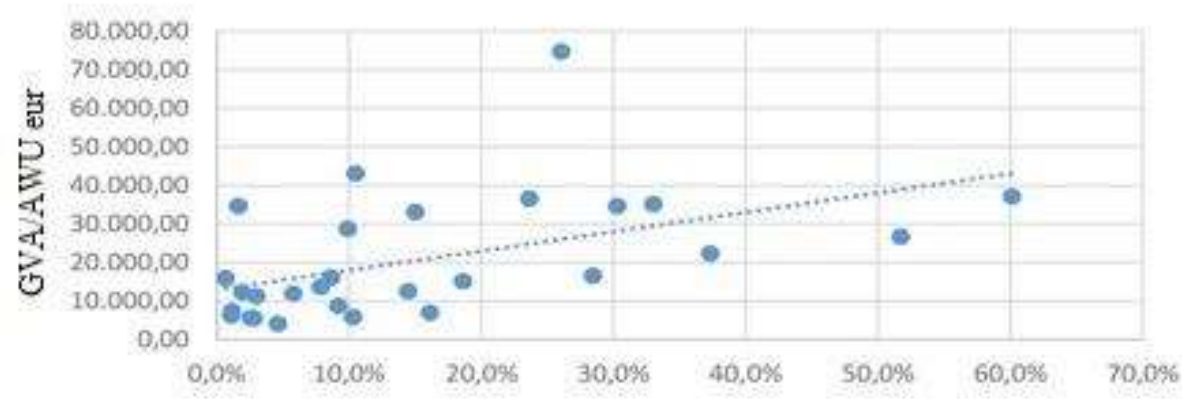

Diversific. agricult. holdings

Source: Hadelan et al., 2019

According to the indicator of gross value added per unit of labor, Croatia is among the least positioned EU member states. In addition, the decrease in the value of this indicator points to poor general trends in Croatian agriculture and is in contrast to the convergent development assumptions of the less developed Member States. The results of the correlation analysis indicate the possibility of improving this indicator among other activities, which, in addition to economic activities, have positive social effects in the form of opportunities for self-employment of young and vital members of the rural population.

\section{Impact of supplementary activities on the size, type, age and educational structure of employed farms}

The size of the economy in numerous studies has proven to be an important factor in diversification. Some have indicated that larger economies are more prone to diversify agricultural activities than smaller ones (Ilbery, 1991; Pope \& Prescott, 1980). On the other hand, some of the researchers, Krugman (1991), Mishra et al. (2004), Vik \& McElwee (2011) conclude that larger economies are more prone to specialization, which emphasizes the benefits of economies of scale.

Using the scatterplot and calculating the correlation coefficient, the relationship between the size of agricultural holdings in the EU28 and the 
share of agricultural holdings with subsidiary activities was examined. The premise of this correlation is the existence of a positive link since larger economies can make more efficient use of available human and productive resources.

Figure 3: Relationship between the share of the agricultural holding with additional activities and the size of the agricultural holding in the EU28, 2013

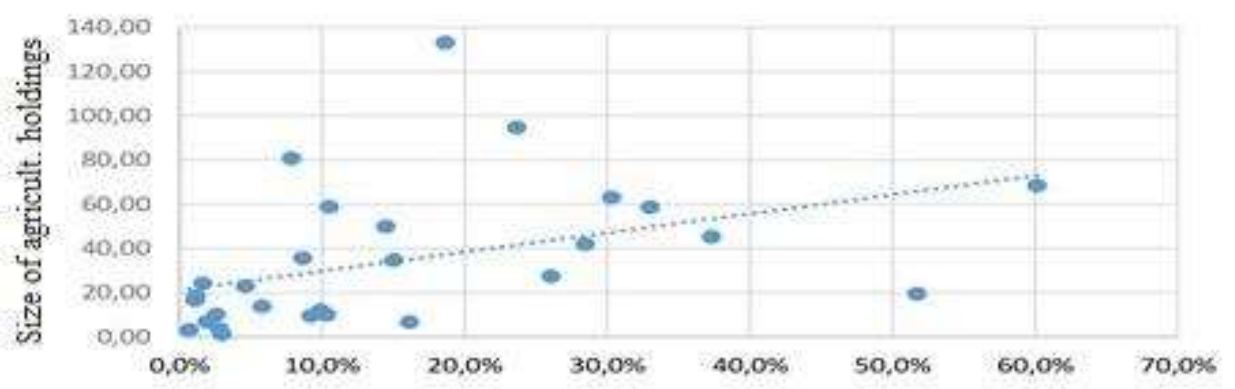

Diversific. agricult. holdings

Source: Hadelan et al., 2019

A correlation analysis including data on shares of holdings with ancillary activities in the EU28 and the average area used in the Member States indicated a statistically significant correlation between the two variables ( $\mathrm{p}$ $=0.0251$ ), which with a correlation coefficient of 0.4226 may be considered as medium and positive.

Croatia is also lagging behind the more developed countries of the Union in terms of average size of the economy. As in the rest of the EU28, there is a trend of increasing economies which, according to the results of the correlation analysis, could also result in an increase in the share of supplementary economies. However, one must take into account the specificity of Croatia, the southern part of which belongs to the circle of Mediterranean countries (Italy, Greece, Cyprus, Italy), in which the specificities of relief, climate, karst areas make it difficult to develop large farms. On the other hand, the tourist orientation of the country favors the development of spatially small, but supplementary farms with agrotourism services (Ružić et al., 2011) and traditionally produced food delicacies. In such circumstances, it is possible to expect an increase in the number and 
share of supplementary economies, which does not necessarily determine the increase in the size of the economy.

Farm typology is made in line with that of Farm Survey (2013). Depending on the prevailing activity, economies are divided into seven types. The predominant type in the EU28, in 2013, was "Ratarstvo" present in approximately $30 \%$ of all EU economies. Correlation analysis revealed statistically significant correlation between prevailing agricultural activity and diversification for three of the seven analyzed types of economy. The correlation is medium positive on the example of "Livestock with grazing", while medium is negative for the type "Mixed crop production and" Mixed livestock breeding ". In other examples, no statistically significant association was found.

Table 1: Correlation of field share. $m r$. with additional activities and field types. Mr, EU28, 2013

\begin{tabular}{|c|c|c|c|c|c|c|c|}
\hline & Farming & Horticulture & $\begin{array}{c}\text { Perennial } \\
\text { crops }\end{array}$ & $\begin{array}{c}\text { Livestock } \\
\text { with } \\
\text { grazing }\end{array}$ & $\begin{array}{c}\text { Mixed } \\
\text { crop } \\
\text { production }\end{array}$ & $\begin{array}{c}\text { Mixed } \\
\text { livestock }\end{array}$ & $\begin{array}{c}\text { Farming } \\
\text { and } \\
\text { livestock } \\
\text { production }\end{array}$ \\
\hline $\mathrm{R}$ & 0.2605 & -0.1267 & -0.3501 & 0.4827 & -0.4687 & -0.3856 & -0.3270 \\
\hline$p$ & 0.1808 & 0.5209 & 0.0679 & 0.0093 & 0.0120 & 0.0427 & 0.0894 \\
\hline
\end{tabular}

Source: Hadelan et al., 2019

In parts of Croatia, primarily in areas with the most unfavorable demographic characteristics, unused pastures and meadows are the problem, with a large area of agricultural land. At the same time, livestock rearing is prevalent with a decline in economically rearing indicators and a continuous increase in meat imports. Keeping livestock outdoors is sporadic with few livestock breeding farms despite favorable conditions for such. Extensive pasture farming is the cheapest way to keep and feed livestock that best meets animal welfare requirements. At the same time, according to the results of the analysis, it offers the best diversification opportunities through agrotourism, breeding traditional animal breeds and production of meat and dairy products.

A number of studies address the link between farmers' age and their propensity to diversify. Finocchio and Esposti (2008), on a sample of 387 farms in Italy, conclude that as farmers age increases, farmers' interest in diversification activities that deepens existing agricultural production increases - direct sales, transition to organic farming, production complying 
with quality standards, but not and non-agricultural activities on the farm agritourism, service activities, employment outside the farm. Somewhat different claims are made by Morris et al. (2017) who, by studying activities in rural Wales, conclude that younger and more educated farmers tend to diversify. This claim is justified by the need to acquire additional management skills that bring about changes in the holding when diversifying activities, which older farmers are not motivated to do.

A glance at the 2016 Labor Force Survey (LFS) data shows that the proportion of farmers with the highest educational attainment is higher in members with more advanced agriculture. The most educated farmers are in the UK (25.5\% with university degrees), Germany and Austria, while the least educated farmers are in Romania (1.6\%). Unfortunately, the same source does not provide information on the educational structure of Croatian farmers, but it can be assumed that this indicator is also at the level of less developed Member States.

The age structure of farmers is also evident from the Labor Force Survey data. Current data refer to the situation in 2017, which shows that in the EU28 age group up to 40 years (young farmers) belongs to $31.7 \%$ of the agricultural population, while at the economy level as a whole, $42.4 \%$ of employees are in the same age group. On the other hand, $65 \%$ and over have $9 \%$ of farmers in the EU28, while in the same age group, only $2.4 \%$ of employees are in the same age group. The highest prevalence of young farmers is in Denmark (44.6\%), while it is the lowest in Portugal (15.9\%). Due to time compliance with the 2013 supplementary activities data, the Labor Force Survey on agricultural contingent work for 2013 was used in the correlation calculation.

The correlation analysis compared the share of young farmers and the share of supplementary activities in EU Member States28. By calculating the Pearson coefficient, no statistically significant correlation was found between these variables $(\mathrm{R}=0.1144, \mathrm{p}=0.5621)$. Unlike the age structure, the correlation between supplementary activities and the educational structure of farmers is statistically significant. The Pearson coefficient calculation found a moderately significant positive correlation between the share of highly educated farmers and supplementary activities in the field. economies in EU member states $(\mathrm{R}=0.5185, \mathrm{p}=0.0113)$. This correlation is offset by the situation in Denmark, with a high proportion of diversified holdings presenting a low proportion of highly educated farmers (10.4\%). 
Figure 4: Field share ratio. $m r$. with additional activities and educational level of the holder, 2013.

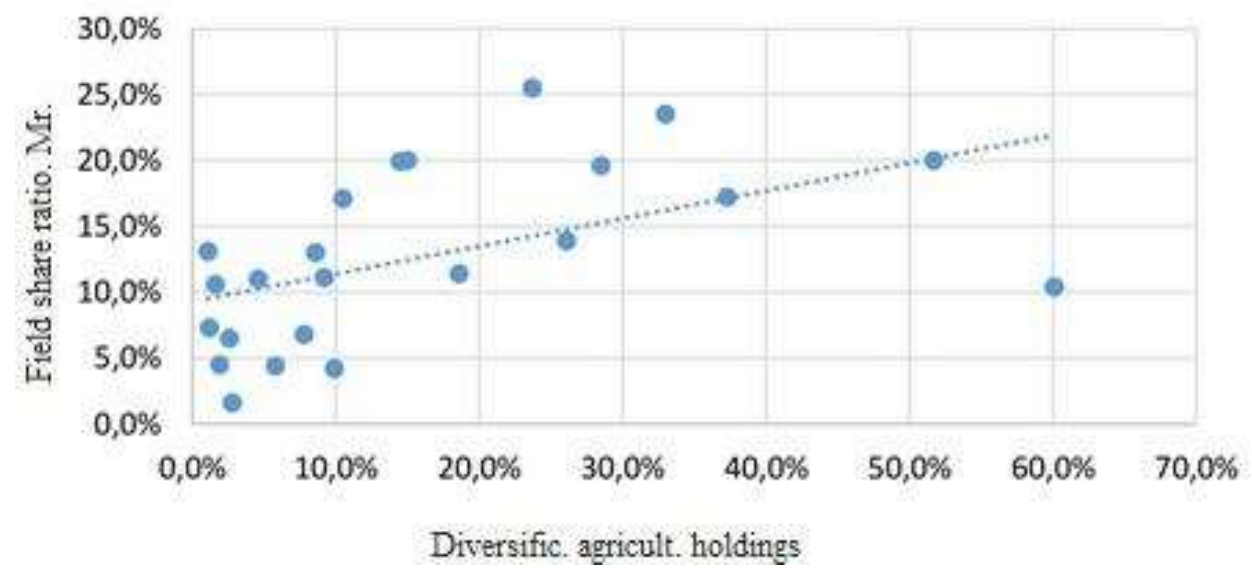

Source: Hadelan et al., 2019

With a share of young farmers in the total agricultural population of $22.5 \%$, in 2013, Croatia was in the penultimate position in the EU28. Only in Portugal was the proportion of young farmers smaller. Things are slightly better in 2017, so the share of this age group of farmers has grown to $28.3 \%$, ranking Croatia 19th in the EU28, according to this indicator. Although the analysis showed no correlation of farmers' age and supplementary activities on farms, it is logical to expect that young, vital rural residents are motivated enough to introduce newspapers into their farms, with less risk aversion and more prone to enrich primary production with supplementary activities. The existing Rural Development Program 2014-2020 (Ministarstvo poljoprivrede, uprava za ruralni razvoj, 2014) will give the criteria for scoring of applied investment projects with priority to younger farmers and specialized sub-measures for them will certainly improve the age structure of farmers and, indirectly, create the preconditions for diversification of farms.

\section{Conclusion}

The basic starting point in this paper was to investigate the impact of farm diversification on agricultural business performance and rural development. The starting point was based on the assumption of work, which was expected to confirm the positive link between diversification of agricultural holdings and development indicators in agriculture and rural areas. 
The survey found that the share of diversified farms is positively correlated with indicators of gross value added per unit of work, size and type of farms, and age and education structure of farmers. The indicators just mentioned are the potential for the development and success of business on farms, and ultimately for the development of rural areas. The above indicators are related to the diversification of the agricultural holding, as introducing additional activities enables the realization of higher gross value added, which causally consequently shape the size and type and age and educational structure of employees on the farm.

On the basis of the above, it can be concluded that the basic assumption of work is fully confirmed in the framework of this research on the example of the EU members. The positive effects of diversification of agricultural holdings on the operations of agriculture and the development of the rural area in which it is realized have been confirmed.

Diversification of agricultural holdings presupposes an opportunity for improvement of macroeconomic indicators of Croatian agriculture and economy in rural areas, but also a necessity for overcoming unfavorable demographic trends. In that sense, the recommendation is directed to Croatia as a Mediterranean country with an important role of tourism and its multiplying effect on agricultural development, modernization and enrichment of the prevailing form of primary agriculture with the most represented low income crops. This may be an acceptable solution for a small number of large and mechanized farms, but not for many small and non-adapted farms.

\section{References}

1. Croatian Bureau of Statistics, (2018a), Struktura BDP-a, https://www.dzs.hr/Hrv_Eng/publication/2018/12-01-04_01_2018_HRV.xlsx, (10 February 2020).

2. Croatian Bureau of Statistics, (2018b), Zaposleni prema sektorima djelatnosti NKD-a 2007, https://www.dzs.hr/Hrv_Eng/Pokazatelji/ MSI\%20ZAPOSLENOST\%20I\%20PLACE.xlsx, (10 February 2020).

3. Europska komisija, (2008), Other Gainful Activities, Pluriactivity and Farm Diversificationin EU-27, https://ec.europa.eu/agriculture/sites/ agriculture/files/rural-area-economics/more-reports/pdf/other-gainfulactivities-text_en.pdf, (10 February 2020). 
4. Europska komisija, (2016), Weight of economic activities, https://ec.europa.eu/eurostat/documents/2995521/7715718/2-27102016AP-EN.pdf/b6dafc70-0390-42f7-8dd2-11ed12e430f8, (10 February 2020).

5. Eurostat according to Farm Survey, (2013), Farm structure survey 2013 - mainresults, https://ec.europa.eu/eurostat/statistics-explained/index.php/ Farm_structure_survey_2013_-_main_results, (10 February 2020).

6. Eurostat, (2018), Agricultural and farm income, https://ec.europa.eu/ agriculture/sites/agriculture/files/statistics/facts-figures/agricultural-farmincome.pdf, (10 February 2020).

7. Eurostat, (2019a), National accounts employment dana by industry, http://appsso.eurostat.ec.europa.eu/nui/show.do?dataset=nama_10_a64_e \&lang=en, (10 February 2020).

8. Eurostat, (2019b), Gross valueadded of the agricultural industry - basic and producer prices, https://ec.europa.eu/eurostat/tgm/table.do?tab= table \&init $=1 \&$ language $=$ en $\&$ pcode $=\operatorname{tag} 00056 \&$ plugin $=1, \quad(10$ February 2020).

9. Falkowski, J., Jakubowski M., Strawinski P. (2014). Returns from income strategies in rural Poland. Economic of transition, Vol. 22, No. 1, 139-178.

10. Finocchio, R., Esposti, R., (2008). Determinants of farm diversification and interaction with the CAP. Anapplication to FADN of Marche region (Italy), 12th Congress of the European Association of Agricultural Economists-EAAE, from 26 to 29 August 2008 in Ghent (Belgium).

11. Franić, R., Mikuš, O. (2013). Transformations in Croatian Agriculture and Agricultural Policy: Challenges and Opportunities within the European Context, in Agriculturein Mediterranean Europe, Between old and new paradigms. Rural Sociology and Development, Vol. 19, 233-261.

12. Hadelan, L., Šakić Bobić, B., Mikuš, O., Zrakić Sušac, M. (2019). Povezanost diversifikacije poljoprivrednog gospodarstva i socioekonomskih pokazatelja. Ekonomska misao i praksa, Vol. 2, No. 2, 69-85. 
13. Ilbery, B.W. (1991). Farm diversification as anadjustment strategy on the urban fringe of the West Midlands. Journal of Rural Studies, Vol. 7, 207-218.

14. Jurković, P., Luković, F., Pribičević, Đ., Ravlić, S. (1995). Poslovni rječnik, Masmedia, Zagreb.

15. Labour Force Survey, (2018), LFS series - detailed quarterly survey results (from 1998 onwards), https://ec.europa.eu/eurostat/web/lfs/data/ database, (10 February 2020).

16. Ministarstvo poljoprivrede, uprava za ruralni razvoj RH, (2014), Program ruralnog razvoja $\mathrm{RH}$ za razdoblje 2014-2020.

17. Mishra, A.K., El-Osta, H.S., Sandretto, C.L. (2004). Factors affecting farm enterprise diversification. Agricultural finance review, Vol. 64, No. 2, 151-166.

18. Morris, W., Henley, A., Dowell, D. (2017). Farm diversification, entrepreneurs hipand technology adoption: Analysis of upland farmers in Wales. Journal of rural studies, 53, 132-143.

19. Mrówczyńska-Kamińska, A., Baer-Nawrocka, A. (2016). The Significance of Agribusiness in the National Economyinthe EU countries. Rural Areas and Development, Vol. 13, 23-35.

20. Official Gazette, (76/2014), Pravilnik o dopunskim djelatnostima na obiteljskim poljoprivrednim gospodarstvima, https://narodne-novine.nn.hr/ clanci/sluzbeni/full/2014_06_76_1436.html, (10 February 2020).

21. Oplanić, M., Milotić, A., Ružić, P. (1997). Obiteljsko poljoprivredno gospodarstvo - čimbenik razvoja ruralnih oblika turizma u Istri. Tourism and Hospitality Managment, Vol. 3, No. 2, 427-440.

22. Pope, R. D., Prescott, R. (1980). Diversification in relation to farm siz and other socioeconomic caracteristics. American Journal of Agricultural Economics, Vol. 62, No. 3, 554-559.

23. Puljiz, V. (2003). Oblici i posljedice deagrarizacije u našem selu. Sociologija i prostor: časopis za istraživanje prostornoga i sociokulturnog razvoja, Vol. 40, No. 3/4, 367-385. 
24. Ružić, P., Amidžić, D. (2018). Identification and analysis of indicators on sustainable tourism development of Istria (Croatia). TISC - Tourism International Scientific Conference, Vrnjačka Banja, Vol. 3, No. 2, 134152.

25. Ružić, P., Amidžić, D., Ružić, T. (2011). Ocjena atraktivnosti i projektiranje ruralne turističke destinacije Istre. Znanstveno-stručni skup s međunarodnim sudjelovanjem - Projekti i projektni menadžment, Zaprešić, 761-771.

26. Ružić, P., Bošković, D., Amidžić, D. (2006). Logistika u funkciji oblikovanja kvalitetnog turističkog proizvoda, Poslovna logistika u suvremenom menadžmentu, VI. Znanstveni kolokvij, Sveučilište Josipa Jurja Strossmayera u Osijeku, Osijek, 122-132.

27. Ružić, P., Demonja, D. (2017). Economic Impacts of Rural Tourism in Rural Areas of Istria (Croatia). Transformation in Business and Economics, Vol. 16, No. 3, 31-40.

28. Sudarić, T. (2009). Diverzifikacija gospodarskih aktivnosti u funkciji cjelovitog ruralnog razvitka Republike Hrvatske - doktorska disertacija, Ekonomski fakultet, Sveučilište u Osijeku.

29. Vik, J., McElwee, G. (2011). Diversification and the Entrepreneurial Motivations of Farmers in Norway. Journal of Small Business Management, Vol. 49, No. 3, 390-410.

30. Župančić, M. (2005). Obiteljsko poljoprivredno gospodarstvo i ruralni razvitak u Hrvatskoj. Sociologija sela, Vol. 167, No. 1, 171-194. 